Buletin Ilmiah Math. Stat. dan Terapannya (Bimaster)

Volume 09, No. 1 (2020), hal 223-230.

\title{
MINIMUM SPANNING TREE PADA JARINGAN FIBER OPTIC DI UNIVERSITAS TANJUNGPURA
}

\author{
Neno Juli Triami, Yundari , Fransiskus Fran
}

\begin{abstract}
INTISARI
Jaringan fiber optic merupakan suatu jaringan kabel yang dapat mentransmisikan sinyal cahaya dari suatu lokasi ke lokasi lainnya dengan kecepatan tinggi. Dibandingkan dengan kabel lainnya, kabel fiber optic ini cenderung lebih tahan lama, lebih cepat dalam mengirim sinyal cahaya. Namun demikian, harganya relatif lebih mahal dari kabel yang lainnya. Oleh karena itu diperlukan cara untuk meminimalisir jaringan pada jaringan fiber optic, salah satu caranya dapat menggunakan minimum spanning tree. Pada saat ini, di Universitas Tanjungpura sudah menggunakan jaringan fiber optic untuk akses internet dari satu unit ke unit yang lainnya. Dalam penelitian ini dibahas mengenai penerapan beberapa algoritma sebagai alternatif untuk mendapatkan MST pada jaringan fiber optic di Universitas Tanjungpura. Hasil penelitian menunjukkan jika menggunakan algoritma Kruskal, algoritma Prim, dan algoritma Sollin diperoleh panjang jaringan kabel yaitu 4310 meter sedangkan sebelum menggunakan MST diperoleh panjang kabel sebesar 8765 meter. Selanjutnya, untuk jaringan fiber optic yang terbentuk dari algoritma Kruskal dan algoritma Prim menghasilkan jaringan yang sama, namun untuk algoritma Sollin berbeda. Perbedaannya terletak pada akses dari Fakultas Hukum ke Rumah Sakit Untan dan dari Fakultas Ekonomi dan Bisnis ke Fakultas Kedokteran.
\end{abstract}

Kata Kunci : algoritma Kruskal, algoritma Prim, algoritma Sollin

\section{PENDAHULUAN}

Akses internet menjadi sesuatu yang harus dimiliki oleh setiap orang, dikarenakan segala informasi yang dibutuhkan akan diperoleh apabila terhubung dengan internet. Penyedia layanan akses internet berlomba-lomba menghadirkan akses internet dengan kualitas yang baik, cepat, dan murah. Penyedia layanan internet banyak menggunakan jaringan fiber optic dalam menunjang kebutuhan akses internet bagi para konsumennya. Jaringan fiber optic adalah suatu jaringan kabel yang digunakan untuk mentransmisikan sinyal cahaya dari suatu lokasi ke lokasi lainnya dengan kecepatan tinggi. Jika dibandingkan dengan kabel lainnya, kabel fiber optic ini cenderung lebih tahan lama dan lebih cepat dalam mengirim sinyal cahaya. Namun, dari segi harganya relatif lebih mahal dari kabel yang lainnya.

Untuk lebih menghemat dalam proses pemasangan, diperlukan suatu metode yang dapat meminimalisir jaringan fiber optic agar lebih efisien [1]. Dalam teori graf terdapat istilah yang digunakan untuk meminimalisir sebuah jaringan, yaitu minimum spanning tree (MST). MST adalah sebuah graf berbobot terhubung (spanning tree) yang memiliki jumlah bobot minimum dari setiap sisi [2]. Dalam mempermudah pencarian MST, ilmuan terdahulu sudah melakukan penelitian dan pengembangan untuk mendapatkan algoritma yang digunakan untuk menyelesaikan MST. Pada tahun 1956, ilmuan yang bernama Joseph Kruskal menemukan algoritma yang diberi nama algoritma Kruskal, kemudian diikuti oleh ilmuan-ilmuan yang lain seperti Robert C. Prim (1957) dan Georges Sollin (1961). Hingga saat ini algoritma-algoritma tersebut sering digunakan dalam mencari MST.

Pada saat ini, di Universitas Tanjungpura sudah menggunakan kabel fiber optic untuk akses internet di setiap unit. Namun dalam penerapannya masih belum efektif, dikarenakan banyaknya kabel yang digunakan. Oleh karena itu, dalam skripsi ini dibahas mengenai MST pada jaringan fiber optic yang terdapat di Universitas Tanjungpura. Penelitian ini dimulai dengan mencari data dari jaringan fiber optic di Universitas Tanjungpura, yang kemudian direpresentasikan dalam bentuk graf. Selanjutnya menerapkan data tersebut ke dalam bentuk MST dengan menggunakan tiga algoritma, yaitu algoritma Kruskal, algoritma Prim, dan algoritma Sollin. 


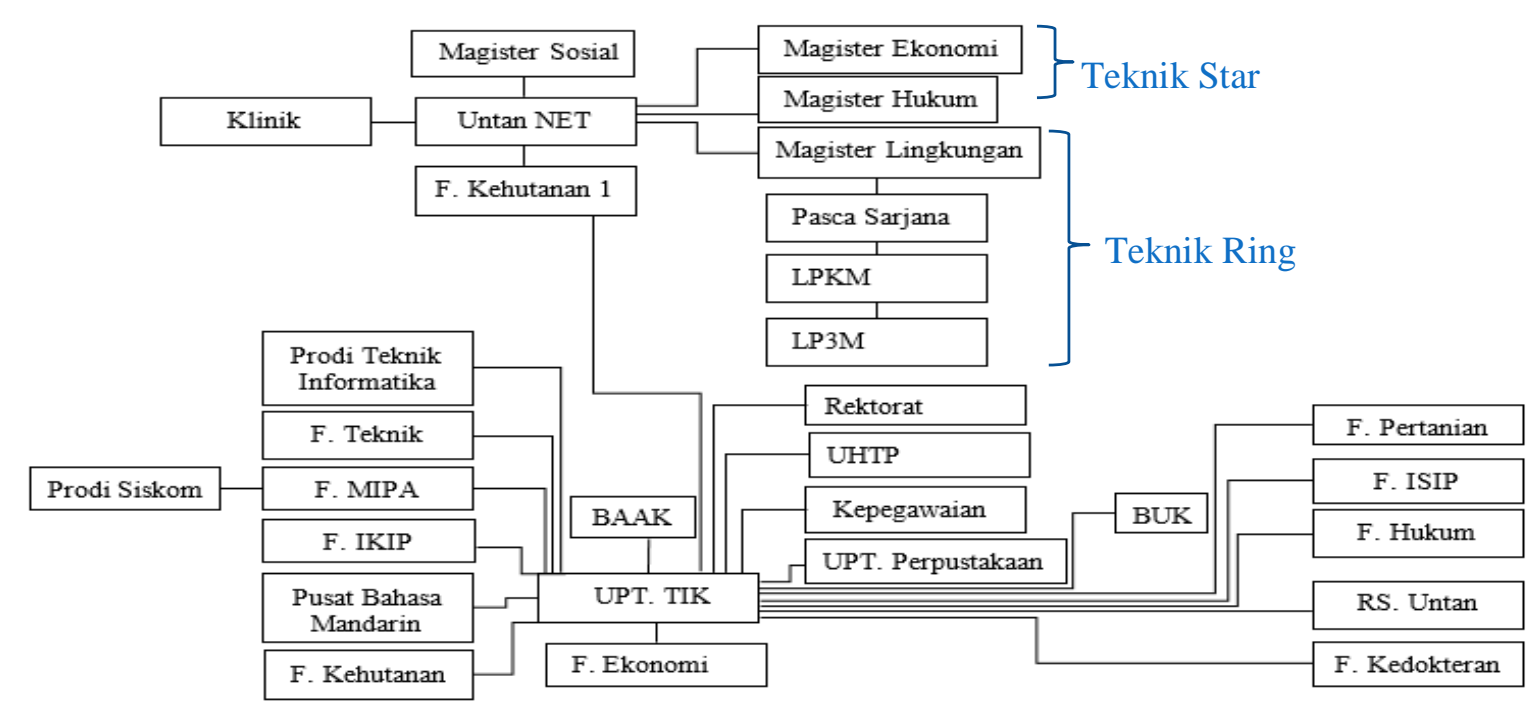

Gambar 1 Jaringan Fiber Optic di Universitas Tanjungpura

\section{JARINGAN FIBER OPTIC DI UNIVERSITAS TANJUNGPURA}

Jaringan fiber optic di Universitas Tanjungpura digunakan untuk menunjang kebutuhan akses internet bagi mahasiswa, pengajar, maupun karyawan dalam ruang lingkup Universitas Tanjungpura. Adapun saat ini di Universitas Tanjungpura telah digunakan jaringan fiber optic yang dipasang dengan teknik ring dan teknik star. Pemasangan menggunakan teknik ring dilakukan dengan cara menghubungkan kabel fiber optic ke setiap tempat secara seri, sedangkan teknik star secara pararel. Pada Gambar 1 dapat dilihat masing-masing contoh teknik ring dan teknik star. Adapun contoh dari teknik ring adalah akses jaringan fiber optic dari Untan NET sampai dengan LP3M. Contoh dari teknik star adalah akses jaringan fiber optic dari Untan NET ke Magister Ekonomi dan Untan NET ke Magister Hukum. Setiap teknik tersebut memiliki kelemahan dan kelebihan yang berbeda. Untuk teknik ring yaitu lebih hemat dalam biaya pemasangan karena menggunakan sedikit kabel, tetapi pada saat pengoperasian jika terdapat kerusakan pada salah satu bagian jaringan maka berdampak pada seluruh jaringan. Sedangkan untuk teknik star yaitu jika terdapat kerusakan pada salah satu bagian jaringan tidak berdampak pada seluruh jaringan, tetapi biaya pemasangannya relatif mahal.

\section{HASIL DAN PEMBAHASAN}

Langkah pertama yang dilakukan adalah mencari data unit di Universitas Tanjungpura yang terhubung dengan jaringan fiber optic, seperti yang terlihat pada Gambar 1. Kemudian mencari total panjang jaringannya dengan menggunakan aplikasi Google Earth, diperoleh sebesar 8765 meter. Selanjutnya adalah membuat jaringan baru yang akan dibandingkan dengan jaringan saat ini. Jaringan baru ini dibentuk dengan menghubungkan setiap unit yang saling berdekatan, agar menghasilkan MST dengan bobot minimum.

Langkah berikutnya adalah menerapkan jaringan tersebut menjadi sebuah graf $G=(V, E)$ dengan memisalkan setiap unit sebagai simpul pada graf $G$, yaitu: $v_{1}=\mathrm{UPT}$. TIK, $v_{2}=\mathrm{FEB}, v_{3}=\mathrm{F}$. Kehutanan $2, v_{4}=\mathrm{FK}, v_{5}=\mathrm{RS}$ Untan, $v_{6}=$ Pusat Bahasa Mandarin, $v_{7}=$ Perpustakaan Untan, $v_{8}=$ BAAK, $v_{9}=$ UHTP, $v_{10}=$ Kepegawaian, $v_{11}=$ BUK, $v_{12}=$ Rektorat, $v_{13}=$ FKIP, $v_{14}=$ FMIPA, $v_{15}=$ Prodi Siskom, $v_{16}=\mathrm{FH}, v_{17}=$ FISIP, $v_{18}=\mathrm{F}$. Pertanian, $v_{19}=\mathrm{FT}, v_{20}=$ Prodi Teknik Informatika, $v_{21}=$ LPKM, $v_{22}=$ LP3M, $v_{23}=$ Pasca Sarjana, $v_{24}=$ F. Kehutanan $1, v_{25}=$ Magister Lingkungan, $v_{26}=$ Klinik Untan, $v_{27}=$ Untan NET, $v_{28}=$ Magister Hukum, $v_{29}=$ Magister Management, $v_{30}=$ Magister Sosial. Selanjutnya memisalkan akses yang menghubungkan setiap unit sebagai sisi pada graf $G$, dan jarak pada akses yang menghubungkan setiap unit sebagai bobot dari graf. Sehingga terbentuk graf $G$ dengan 30 simpul dan 55 sisi, seperti yang terlihat pada Gambar 2. 


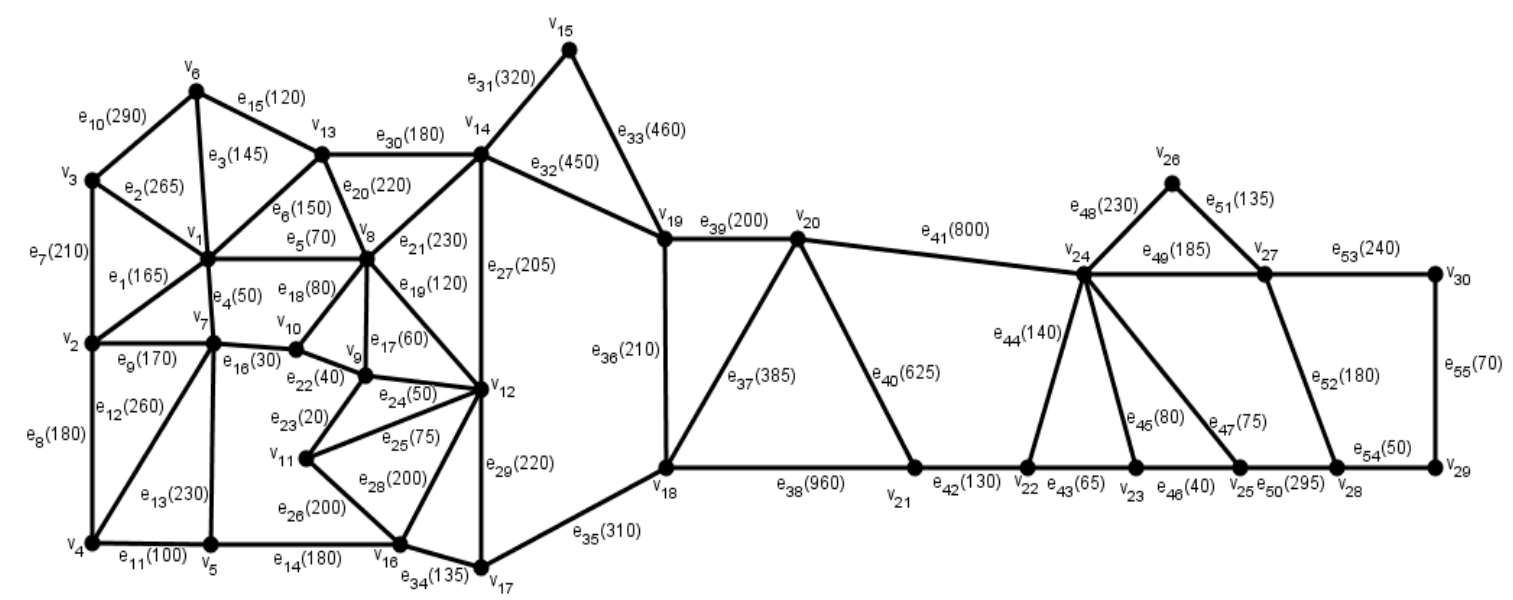

Gambar 2 Graf Berbobot $G$ dengan 30 Simpul dan 55 Sisi

Adapun penerapan MST pada algoritma Kruskal, algoritma Prim, dan algoritma Sollin dapat dilihat sebagai berikut:

1. Algoritma Kruskal

Algoritma Kruskal dapat diasumsikan dengan memilih sisi dari graf secara berurutan berdasarkan bobotnya dari bobot kecil ke bobot besar [3]. Diketahui $G$ merupakan graf dari jaringan fiber optic baru di Universitas Tanjungpura. Selanjutnya, dimisalkan $T$ merupakan MST yang akan dibuat, $V$ merupakan himpunan simpul, dan $E$ merupakan himpunan sisi. Mula-mula graf $T$ memuat semua simpul di graf $G$ tanpa sisi, sedemikian sehingga $V(T)=\left\{v_{1}, v_{2}, v_{3}, \ldots, v_{30}\right\}$ dan $E(T)=\{\}$. Setelah itu, pilih sisi di $E(G)$ yang mempunyai bobot minimum dan tidak membentuk sirkuit, kemudian subtitusikan pada $E(T)$. Dipilih sisi $e_{23}$ dengan bobot 20, sedemikian sehingga $E(T)=\left\{e_{23}\right\}$, terlihat pada Gambar 3.

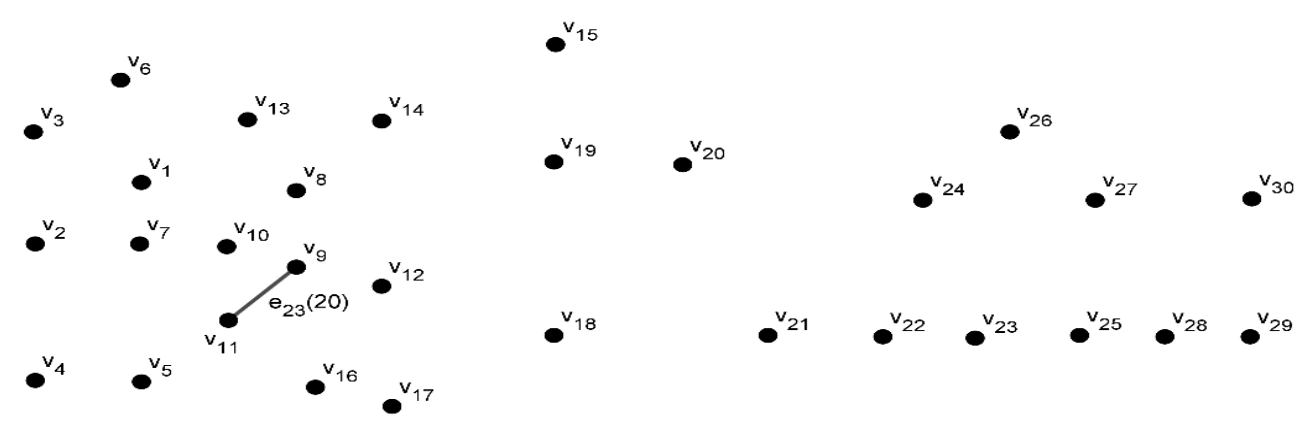

Gambar 3 Simpul yang Berjumlah 30 dan Sebuah Sisi pada Graf $T$

Pengerjaan dilakukan hingga semua simpul dalam graf $T$ terhubung dan tidak membentuk sirkuit. Tabel 2 merupakan langkah pengerjaan dari penerapan MST pada jaringan fiber optic di Universitas Tanjungpura dengan algoritma Kruskal.

\section{Tabel 1 Langkah Pengerjaan Algoritma Kruskal}

\begin{tabular}{cl}
\hline Langkah ke- & \multicolumn{1}{c}{ Keterangan } \\
\hline 1 & Graf $T$ memuat semua titik di graf $G$ tanpa sisi \\
2 & Tambahkan sisi $e_{23}$ dengan bobot 20 di $E(T)$ \\
3 & Tambahkan sisi $e_{16}$ dengan bobot 30 di $E(T)$ \\
4 & Tambahkan sisi $e_{22}$ dan $e_{45}$ dengan bobotnya 40 di $E(T)$ \\
5 & Tambahkan sisi $e_{22}, e_{24}$ dan $e_{54}$ dengan bobot 50 di $E(T)$ \\
6 & Tambahkan sisi $e_{17}$ dengan bobot 60 di $E(T)$ \\
7 & Tambahkan sisi $e_{43}$ dengan bobot 65 di $E(T)$ \\
8 & Tambahkan sisi $e_{55}$ dengan bobot 70 di $E(T)$ \\
9 & Tambahkan sisi $e_{47}$ dengan bobot 75 di $E(T)$ \\
\hline
\end{tabular}




\begin{tabular}{cl}
\hline Langkah ke & \multicolumn{1}{c}{ Keterangan } \\
\hline 10 & Tambahkan sisi $e_{46}$ dengan bobot 80 di $E(T)$ \\
11 & Tambahkan sisi $e_{11}$ dengan bobot 100 di $E(T)$ \\
12 & Tambahkan sisi $e_{15}$ dengan bobot 120 di $E(T)$ \\
13 & Tambahkan sisi $e_{42}$ dengan bobot 130 di $E(T)$ \\
14 & Tambahkan sisi $e_{51}$ dengan bobot 135 di $E(T)$ \\
15 & Tambahkan sisi $e_{3}$ dengan bobot 145 di $E(T)$ \\
16 & Tambahkan sisi $e_{1}$ dengan bobot 165 di $E(T)$ \\
17 & Tambahkan sisi $e_{28}$ dengan bobot 170 di $E(T)$ \\
18 & Tambahkan sisi $e_{8}, e_{30}$ dan $e_{52}$ dengan bobot 180 di $E(T)$ \\
19 & Tambahkan sisi $e_{49}$ dengan bobot 185 di $E(T)$ \\
20 & Tambahkan sisi $e_{34}$ dengan bobot 195 di $E(T)$ \\
21 & Tambahkan sisi $e_{39}$ dengan bobot 200 di $E(T)$ \\
22 & Tambahkan sisi $e_{7}$ dan $e_{36}$ dengan bobot 210 di $E(T)$ \\
23 & Tambahkan sisi $e_{35}$ dengan bobot 310 di $E(T)$ \\
24 & Tambahkan sisi $e_{31}$ dengan bobot 320 di $E(T)$ \\
25 & Tambahkan sisi $e_{40}$ dengan bobot 625 di $E(T)$ \\
\hline
\end{tabular}

Setelah semua titik dalam $T$ terhubung dan tidak membentuk sirkuit sehingga diperoleh $V(T)=$ $\left\{v_{1}, v_{7}, v_{10}, \ldots, v_{30}\right\}$ dan $E(T)=\left\{e_{23}, e_{16}, \ldots, e_{40}\right\}$ dengan bobot total sebesar 4310 meter. Gambar 4 merupakan MST jaringan fiber optic baru di Universitas Tanjungpura dengan menggunakan algoritma Kruskal dan algoritma Prim.

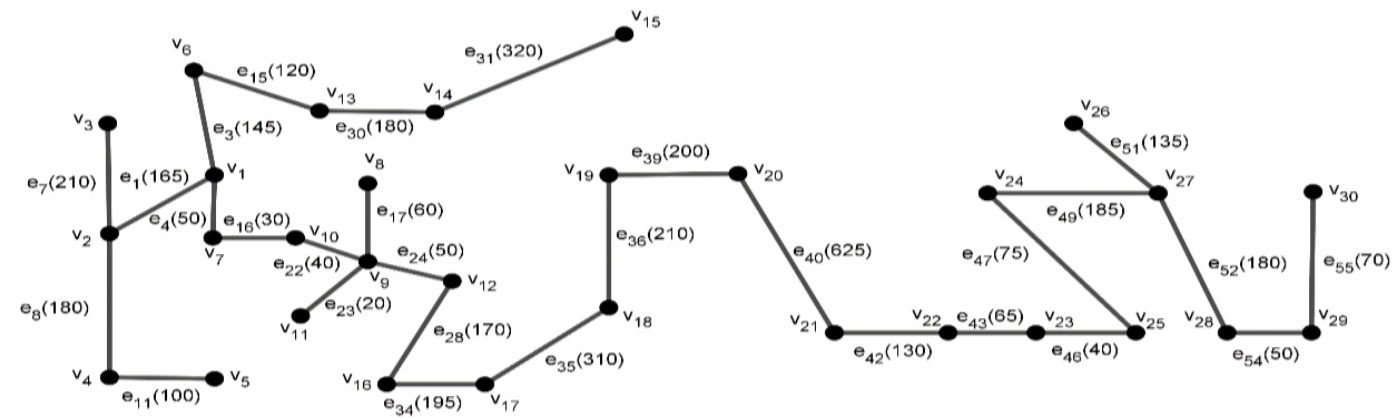

Gambar 4 Hasil MST dengan Algoritma Kruskal dan Algoritma Prim

\section{Algoritma Prim}

Algoritma Prim ini dimulai dari graf yang kosong sama sekali, kemudian dipilih sebarang simpul, selanjutnya simpul tersebut dihubungkan dengan sisi yang bersesuaian dan memiliki bobot yang paling kecil [4]. Diketahui $G$ merupakan graf dari jaringan fiber optic baru di Universitas Tanjungpura. Selanjutnya, dimisalkan $T$ merupakan MST yang akan dibuat, $V$ merupakan himpunan simpul, dan $E$ merupakan himpunan sisi. Mula-mula dipilih sebarang simpul pada graf $G$ dan ditambahkan pada graf $T$, sehingga $V(T)=\left\{v_{1}\right\}$ dan $E(T)=\{\}$, terlihat pada Gambar 5 (a).

Pada langkah selanjutnya pilih sisi $e \in E(G)$ yang berhubungan dengan simpul di $V(G)$ dengan bobot terkecil dan tidak membentuk sirkuit, kemudian disubtitusikan pada $E(T)$ dan $V(T)$. Terdapat enam sisi yang berhubungan dengan titik $v_{1}$ yaitu $e_{1}, e_{2}, e_{3}, e_{4}, e_{5}$ dan $e_{6}$ dengan masing-masing bobotnya adalah $165,265,145,50,70$ dan 150. Kemudian pilih sisi $e_{4}$ dengan bobot 50 yang menghubungkan $v_{1}$ dan $v_{7}$. Sedemikian sehingga $V(T)=\left\{v_{1}, v_{7}\right\}$ dan $E(T)=\left\{e_{4}\right\}$, seperti yang terlihat pada Gambar 5 (b). Pada langkah selanjutnya dengan pengerjaan yang sama, hingga $V(T)$ memuat semua simpul dalam $G$. Tabel 3 merupakan langkah pengerjaan dari penerapan MST pada jaringan fiber optic di Universitas Tanjungpura dengan Algoritma Prim.

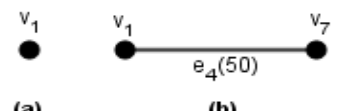

(a) (b)

Gambar 5 Proses Pengerjaan MST pada Algoritma Prim 
Tabel 2 Langkah Pengerjaan pada Algoritma Prim

\begin{tabular}{|c|c|}
\hline Langkah ke- & Keterangan \\
\hline 1 & Mula-mula $V(T)=\{\}$ dan $E(T)=\{\}$ \\
\hline 2 & Pilih titik $v_{1}$ di $V(T)$ \\
\hline 3 & Tambahkan $v_{7}$ di $V(T)$ dan $e_{4}$ di $E(T)$ dengan bobot 50 \\
\hline 4 & Tambahkan $v_{10}$ di $V(T)$ dan $e_{16}$ di $E(T)$ dengan bobot 30 \\
\hline 5 & Tambahkan $v_{9}$ di $V(T)$ dan $e_{22}$ di $E(T)$ dengan bobot 40 \\
\hline 6 & Tambahkan $v_{11}$ di $V(T)$ dan $e_{23}$ di $E(T)$ dengan bobot 20 \\
\hline 7 & Tambahkan $v_{12}$ di $V(T)$ dan $e_{24}$ di $E(T)$ dengan bobot 50 \\
\hline 8 & Tambahkan $v_{8}$ di $V(T)$ dan $e_{17}$ di $E(T)$ dengan bobot 60 \\
\hline 9 & Tambahkan $v_{6}$ di $V(T)$ dan $e_{3}$ di $E(T)$ dengan bobot 145 \\
\hline 10 & Tambahkan $v_{13}$ di $V(T)$ dan $e_{15}$ di $E(T)$ dengan bobot 120 \\
\hline 11 & Tambahkan $v_{2}$ di $V(T)$ dan $e_{1}$ di $E(T)$ dengan bobot 165 \\
\hline 12 & Tambahkan $v_{16}$ di $V(T)$ dan $e_{28}$ di $E(T)$ dengan bobot 170 \\
\hline 13 & Tambahkan $v_{4}$ di $V(T)$ dan $e_{8}$ di $E(T)$ dengan bobot 180 \\
\hline 14 & Tambahkan $v_{14}$ di $V(T)$ dan $e_{30}$ di $E(T)$ dengan bobot 180 \\
\hline 15 & Tambahkan $v_{5}$ di $V(T)$ dan $e_{11}$ di $E(T)$ dengan bobot 100 \\
\hline 16 & Tambahkan $v_{17}$ di $V(T)$ dan $e_{34}$ di $E(T)$ dengan bobot 195 \\
\hline 17 & Tambahkan $v_{3}$ di $V(T)$ dan $e_{7}$ di $E(T)$ dengan bobot 210 \\
\hline 18 & Tambahkan $v_{18}$ di $V(T)$ dan $e_{35}$ di $E(T)$ dengan bobot 310 \\
\hline 19 & Tambahkan $v_{19}$ di $V(T)$ dan $e_{36}$ di $E(T)$ dengan bobot 210 \\
\hline 20 & Tambahkan $v_{20}$ di $V(T)$ dan $e_{39}$ di $E(T)$ dengan bobot 200 \\
\hline 21 & Tambahkan $v_{15}$ di $V(T)$ dan $e_{31}$ di $E(T)$ dengan bobot 320 \\
\hline 22 & Tambahkan $v_{21}$ di $V(T)$ dan $e_{40}$ di $E(T)$ dengan bobot 625 \\
\hline 23 & Tambahkan $v_{22}$ di $V(T)$ dan $e_{42}$ di $E(T)$ dengan bobot 130 \\
\hline 24 & Tambahkan $v_{23}$ di $V(T)$ dan $e_{43}$ di $E(T)$ dengan bobot 65 \\
\hline 25 & Tambahkan $v_{25}$ di $V(T)$ dan $e_{46}$ di $E(T)$ dengan bobot 40 \\
\hline 26 & Tambahkan $v_{24}$ di $V(T)$ dan $e_{47}$ di $E(T)$ dengan bobot 75 \\
\hline 27 & Tambahkan $v_{27}$ di $V(T)$ dan $e_{49}$ di $E(T)$ dengan bobot 185 \\
\hline 28 & Tambahkan $v_{26}$ di $V(T)$ dan $e_{51}$ di $E(T)$ dengan bobot 135 \\
\hline 29 & Tambahkan $v_{28}$ di $V(T)$ dan $e_{53}$ di $E(T)$ dengan bobot 180 \\
\hline 30 & Tambahkan $v_{29}$ di $V(T)$ dan $e_{54}$ di $E(T)$ dengan bobot 50 \\
\hline 31 & Tambahkan $v_{30}$ di $V(T)$ dan $e_{55}$ di $E(T)$ dengan bobot 70 \\
\hline
\end{tabular}

Setelah $V(T)$ memuat semua simpul dalam $G$ yaitu 30 simpul, sehingga diperoleh $V(T)=$ $\left\{v_{1}, v_{7}, v_{10}, \ldots, v_{30}\right\}$ dan $E(T)=\left\{e_{4}, e_{16}, \ldots, e_{55}\right\}$ dengan bobot total sebesar 4310 meter. Hasil MST pada jaringan fiber optic baru di Universitas Tanjungpura dengan algoritma Prim dapat dilihat pada Gambar 4.

3. Algoritma Sollin

Konsep dari algoritma Sollin adalah memilih wakil sisi dari masing-masing simpul dengan bobot terkecil. Sisi yang telah dipilih tersebut, kemudian dihubungkan untuk menemukan solusi dari MST. Tetapi ada kemungkinan sisi dari masing-masing simpul tersebut akan sama atau duplikat, maka akan ada proses penghapusan sisi yang duplikat tersebut. Selanjutnya, mengelompokkan sisi yang telah terpilih kedalam tree-nya masing-masing. Jika MST sudah terbentuk maka penelitian selesai, namun jika MST belum terbentuk maka hubungkan setiap tree dengan sisi yang paling kecil sampai MST terbentuk [5].

Diketahui graf $G$ merupakan graf dari jaringan fiber optic baru di Universitas Tanjungpura. Selanjutnya, dimisalkan graf $T$ merupakan MST yang akan dibuat, $V$ merupakan himpunan simpul, dan $E$ merupakan himpunan sisi. Mula-mula graf $T$ memuat semua simpul di graf $G$ tanpa sisi, sedemikian sehingga $V(T)=\left\{v_{1}, v_{2}, v_{3}, \ldots, v_{30}\right\}$ dan $E(T)=\{\}$. Selanjutnya pilih wakil sisi yang berbobot minimum dari setiap simpul di $G$, kemudian subtitusi wakil-wakil sisi yang telah terpilih tersebut pada graf $T$, seperti yang terlihat pada Gambar 6, yaitu pada graf $T$ memuat hutan yang di dalamnya terdapat delapan pohon. 


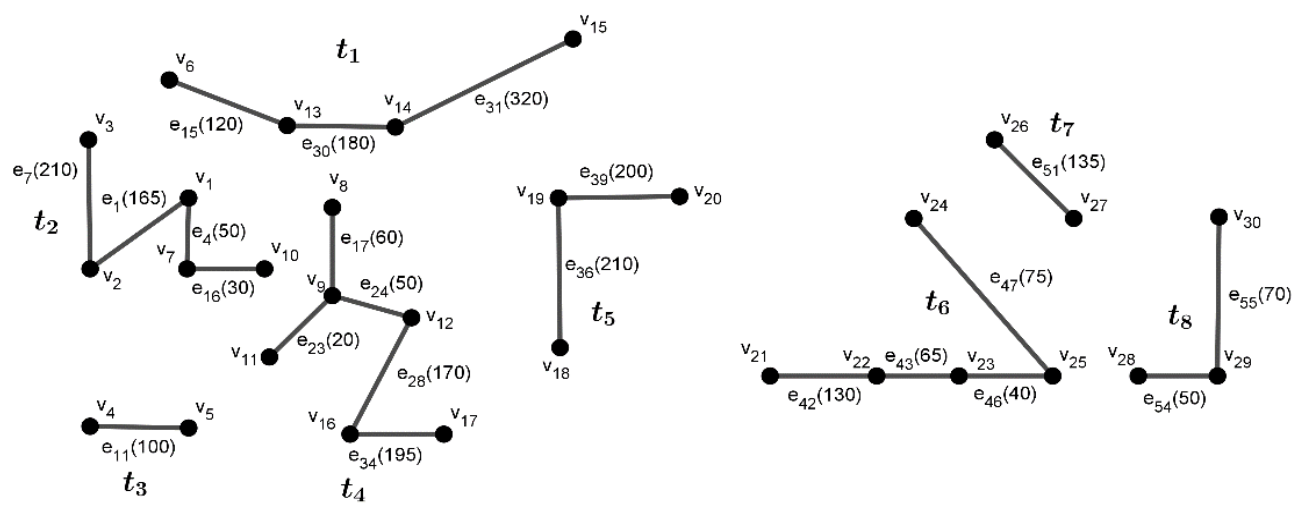

Gambar 6 Hutan yang Memuat Delapan Pohon pada Graf T

Selanjutnya subtitusi sisi dengan bobot paling minimum untuk menghubungkan masing-masing pohon tersebut sampai diperoleh MST pada graf $T$ yaitu sampai jumlah sisinya menjadi $n-1$, dengan $n$ adalah jumlah simpul pada graf $T$. Tabel 5 merupakan langkah pengerjaan dengan algoritma Sollin.

Tabel 3 Langkah Pengerjaan pdengan Algoritma Sollin

\begin{tabular}{|c|c|}
\hline Langkah ke- & Keterangan \\
\hline 1 & Graf $T$ memuat semua simpul di graf $G$ \\
\hline 2 & Pilih wakil sisi dari setiap simpul dengan bobot minimum \\
\hline 3 & $\begin{array}{l}\text { Subtitusi wakil sisi tersebut ke dalam graf } T \text { sehingga diperoleh } \\
22 \text { sisi dengan delapan pohon seperti yang terlihat di Gambar } 3.8\end{array}$ \\
\hline 4 & $\begin{array}{l}\text { Subtitusi sisi } e_{22} \text { dengan bobot } 40 \text { di } E(T) \text { untuk menghubungkan } \\
\text { pohon } t_{2} \text { dan pohon } t_{4}\end{array}$ \\
\hline 5 & $\begin{array}{l}\text { Subtitusi sisi } e_{3} \text { dengan bobot } 145 \text { di } E(T) \text { untuk menghubungkan } \\
\text { pohon } t_{1} \text { dan pohon } t_{2}\end{array}$ \\
\hline 6 & $\begin{array}{l}\text { Subtitusi sisi } e_{14} \text { dengan bobot } 180 \text { di } \\
\text { menghubungkan pohon } t_{3} \text { dan pohon } t_{4}\end{array}$ \\
\hline 7 & $\begin{array}{l}\text { Subtitusi sisi } e_{52} \text { dengan bobot } 180 \text { di } \\
\text { menghubungkan pohon } t_{7} \text { dan pohon } t_{8}\end{array}$ \\
\hline 8 & $\begin{array}{l}\text { Subtitusi sisi } e_{35} \text { dengan bobot } 310 \text { di } \\
\text { menghubungkan pohon } t_{4} \text { dan pohon } t_{5}\end{array}$ \\
\hline 9 & $\begin{array}{l}\text { Subtitusi sisi } e_{49} \text { dengan bobot } 185 \text { di } \\
\text { menghubungkan pohon } t_{6} \text { dan pohon } t_{7}\end{array}$ \\
\hline 10 & $\begin{array}{l}\text { Subtitusi sisi } e_{40} \text { dengan bobot } 625 \text { di } \\
\text { menghubungkan pohon } t_{5} \text { dan pohon } t_{6}\end{array}$ \\
\hline
\end{tabular}

Setelah semua sisi terhubung diperoleh bobot total sebesar 4310 meter. Gambar 7 merupakan Hasil MST pada jaringan fiber optic di Universitas Tanjungpura menggunakan Algoritma Sollin.

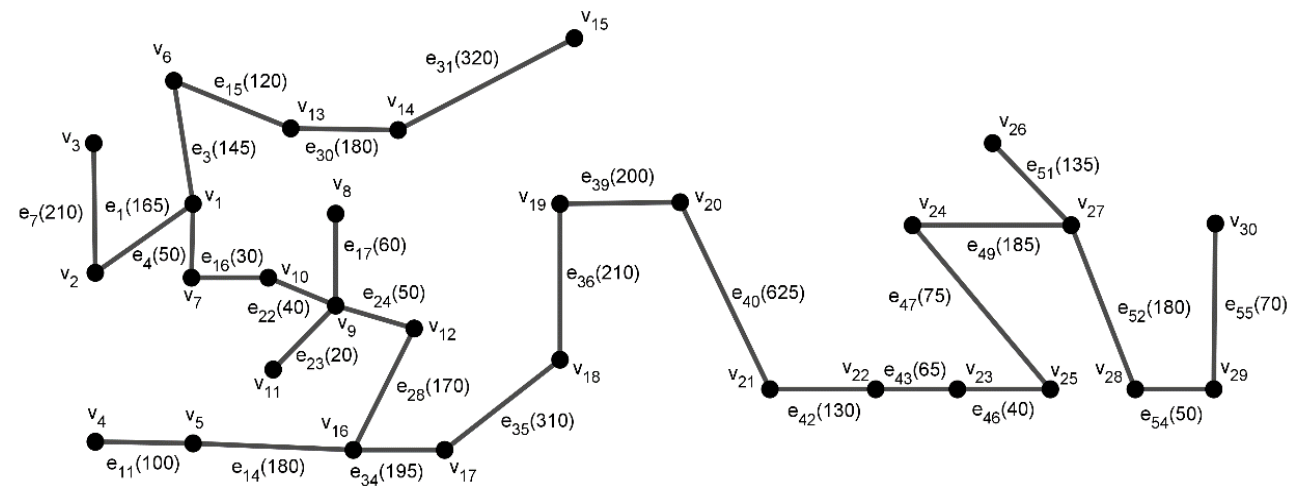

Gambar 7 Hasil MST dengan Algoritma Sollin 
Setelah diperoleh hasil dari setiap algoritma, selanjutnya dibandingkan panjang kabel jaringan fiber optic sebelum dan sesudah menggunakan MST. Panjang kabel jaringan fiber optic sebelum menggunakan MST adalah $8765 \mathrm{~m}$, sedangkan setelah menggunakan MST dengan ketiga algoritma diperoleh hasil yang sama yaitu $4310 \mathrm{~m}$. Sehingga terdapat perbedaan lebih sedikit yaitu $4455 \mathrm{~m}$. Adapun perbedaan jaringan yang terbentuk dari ketiga algoritma dapat dilihat pada Gambar 8 dan Gambar 9. Pada Gambar 8 menunjukkan jaringan yang terbentuk dari algoritma Kruskal dan algoritma Prim. Gambar 9 menunjukkan jaringan yang terbentuk dari algoritma Sollin. Perbedaannya terletak pada akses yang menghubungkan F. Hukum dan RS Untan untuk algoritma Kruskal dan algoritma Prim, sedangkan pada algoritma Sollin terdapat akses yang menghubungkan FEB dan F. Kedokteran.

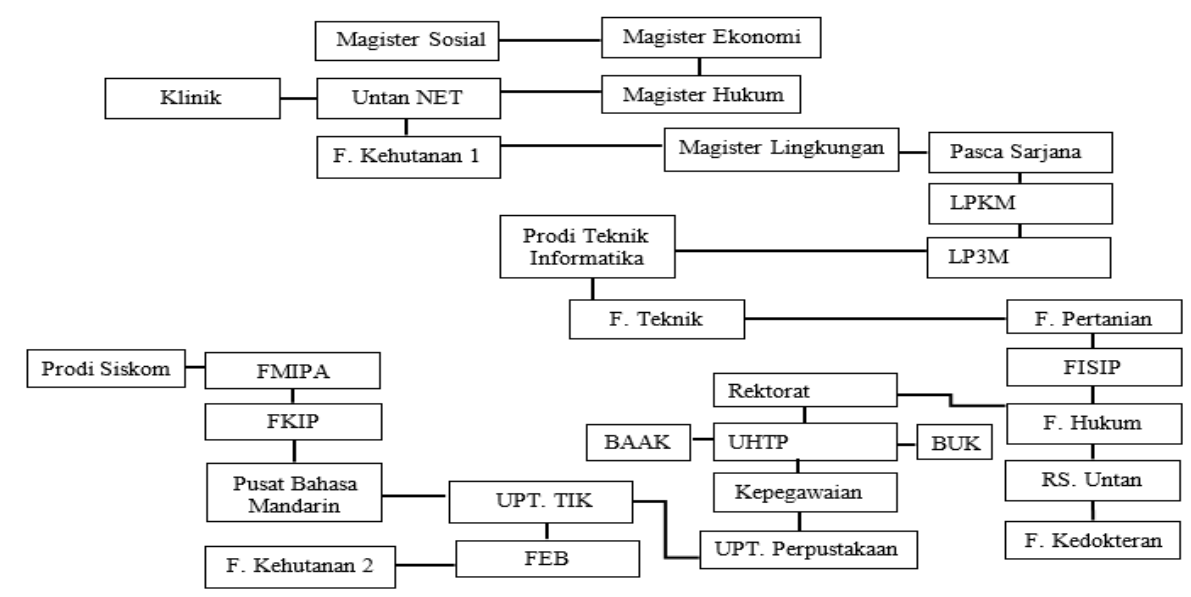

\section{Gambar 8 Jaringan Fiber Optic di Universitas Tanjungpura dengan Algoritma Kruskal dan Algoritma Prim}

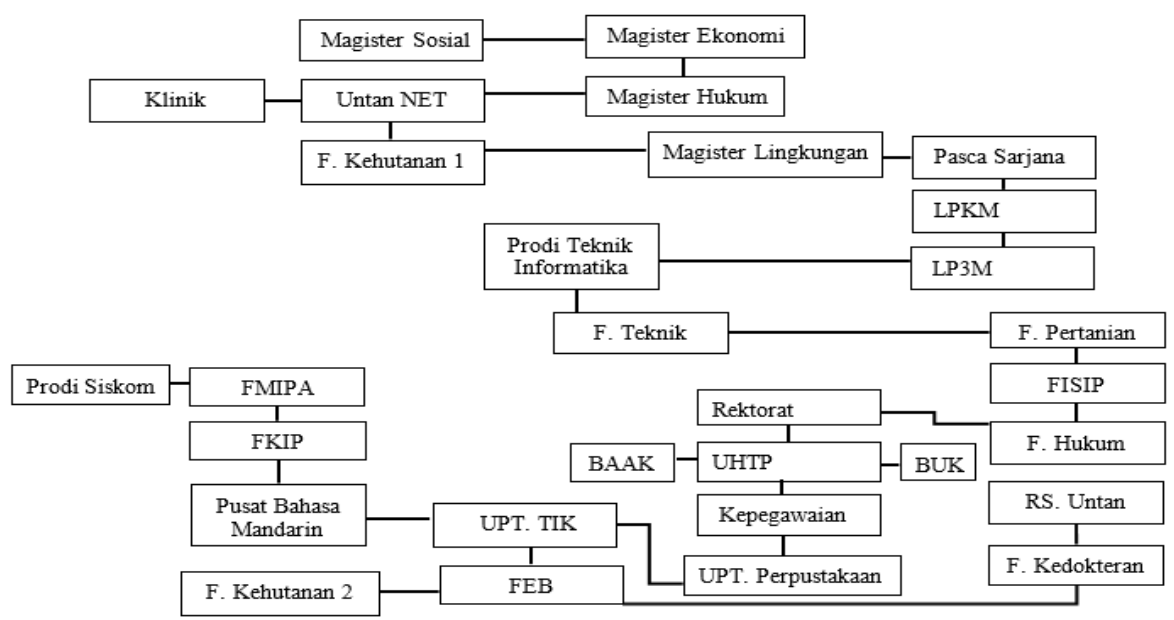

Gambar 9 Jaringan Fiber Optic di Universitas Tanjungpura dengan Algoritma Sollin

\section{PENUTUP}

Berdasarkan proses pengerjaan, diperoleh kesimpulan bahwa pencarian MST pada jaringan fiber optic di Universitas Tanjungpura dengan menggunakan algoritma Kruskal, algoritma Prim, dan algoritma Sollin masing-masing menghasilkan panjang jaringan kabel yang sama yaitu 4310 meter. Sehingga terdapat perbedaan 4455 meter dari sebelum diterapkan menggunakan MST (8765 meter). Kemudian untuk langkah pengerjaan dengan algoritma Kruskal menghasilkan 25 langkah, dengan algoritma Prim menghasilkan 31 langkah sedangkan dengan algoritma Sollin menghasilkan 10 langkah. Selanjutnya untuk jaringan yang terbentuk, algoritma Kruskal dan algoritma Prim menghasilkan jaringan sama. Perbedaannya terletak pada akses dari Fakultas Hukum ke Rumah Sakit Untan dan akses dari Fakultas Ekonomi dan Bisnis ke Fakultas Kedokteran. 


\section{DAFTAR PUSTAKA}

[1] Ramadilesta Y. Pengertian dan Fungsi Kabel Fiber Optik [Internet]. 2018 [Diakases 11 April 2019]. Tersedia di: http://catatanhand.blogspot.com/

[2] Rosen KH. Discrete Mathematic and Its Aplications. Singapore: Mc Graw Hill; 2012.

[3] Siang JJ.Riset Operasi dalam Pendekatan Algoritmis. Yogyakarta: Andi; 2012.

[4] Munir R. Matematika Diskrit. Ed ke 6. Bandung: Informatika; 2016.

[5] Wamiliana, Kurniawan D, Savitri, C. Perbandingan Kompleksitas Algoritma Prim, Algoritma Kruskal dan Algoritma Sollin untuk Menyelesaikan Masalah Minimum Spanning Tree. Jurnal Komputasi. 2014; Vol. 2, No. 1.

NENO JULI TRIAMI : Jurusan Matematika FMIPA Untan, Pontianak nenojuli27@gmail.com

YUNDARI : Jurusan Matematika FMIPA Untan, Pontianak yundari@math.untan.ac.id

FRANSISKUS FRAN : Jurusan Matematika FMIPA Untan, Pontianak fransiskusfran@math.untan.ac.id 